\title{
A Review - Septage Management Related Regulatory and Institutional Aspects and Needs in Sri Lanka
}

\section{S. Fernando*, P. Drechsel, H. Manthrithilake, L. Jayawardena}

* International Water Management Institute, 127, Sunil Mawatha, Pelawatte, Battaramulla, Sri Lanka.s.c.fernando@cgiar.org

\begin{abstract}
Urbanization, population growth and rapid development have created a notable shift in septage* management in Sri Lanka, necessitating a vast and rapid improvement in the service of mechanized septage collection by trucks and finding additional space to meet the increasing septage disposal needs. According to data collected in 2012, $58 \%$ of the Local Authorities (LAs) in Sri Lanka have access to septic truck services. Septage (from septic trucks) appears as a non-traditional and fairly new urban waste stream without proper regulatory and institutional arrangement to manage. This paper contains a comprehensive legal, regulatory and institutional analysis of the present situation, and identify the needs and gaps that need to be filled to establish a sustainable septage management service in Sri Lanka. This review has elicited the need for a new array of regulatory and institutional interventions from national level to local level to manage septage.
\end{abstract}

Key words: Septage, Regulatory aspects, Institutional Aspects

\section{Introduction}

Like in many countries, the governance and the administration structure in Sri Lanka has been divided into three tiers: (a) local level, (b) provincial/regional level, and (c) national level. In each of the three tiers the septage service is delivered by (a) Local Authorities-La (b) Provincial Councils and (c) a host of government ministries, respectively. While exercising its powers to achieve a sustainable outcome in any sector coming under its purview, each authority should carry out their duties with a sense of responsibility so that they are also in a position to meet the needs of the future. This paper aims to map the existing regulatory/legal provisions and institutional aspects while identifying gaps and needs related to septage management. It is noted that non-governmental institutions (e.g., development banks, non-governmental organizations [NGOs], private sector, community-based organizations [CBOs], etc.) also play a significant role in septage management. However, the institutional analysis carried out as part of this study is mainly focused on governmental 
authorities and on related regulatory aspects and needs. However, there are no clear legal provisions stating or encouraging the participation of nongovernmental or private sector institutions in setage management.

In Sri Lanka, septage management seems to have been left out of the spotlight of the authorities until the recent past. The adverse impact that unsustainable septage management is having on health and the environment highlights the need for urgent measures to be taken. The significance and scale of this challenge related to Sri Lanka appears to be high (AECOM International Development Inc. and Sandec/Eawag 2010), but still needs to be quantified. The impact of poor septage management in India has been highlighted by Narain (2012), who states that $80 \%$ of the surface water pollution in the country is related to human excreta. (Hingorani, 2011) also suggests that the main reason for child mortality in India is linked to septage. Sandec/Eawag, IWA and ONAS (2006) estimate that one septic truckload dumped is equal to 5,000 open defecations. This clearly illustrates that septage collection alone does not fulfill the urban service requirements, and having a proper disposal system in place is a vital component of the entire process. An estimated 58\% of the LAs in Sri Lanka have access to septage truck collection facilities (NSWMSC 2012), and there are less than 10 treatment plants in operation. Since unsustainable septage management can undermine sustainable development, it is recommended that the authorities look into the possibilities of preventing the negative consequences of unsustainable septage management before it is too late.

\section{Regulatory and Institutional Analysis}

Regulatory and institutional analysis is conducted in line with the three tiers of the administration structure as shown in Figure 1.

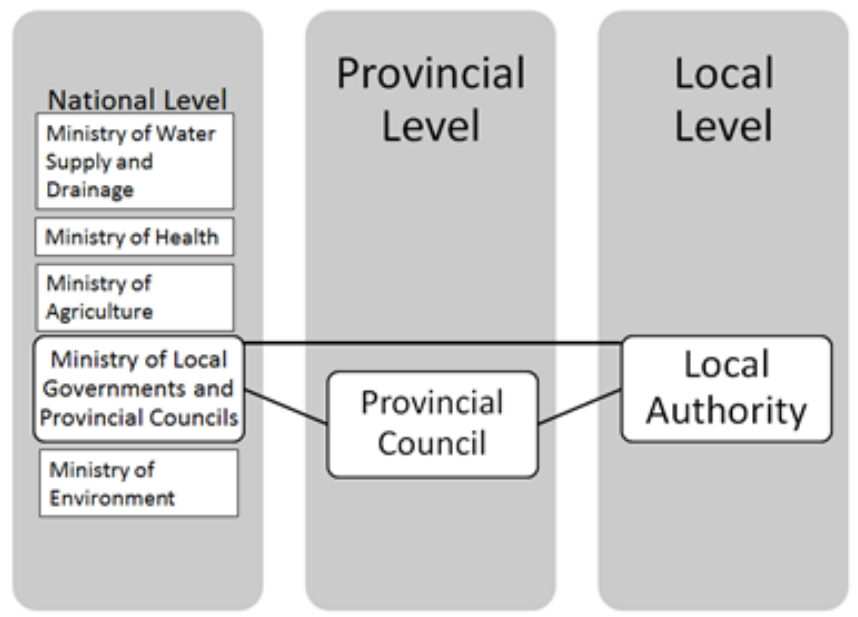

Figure 1 - Major stakeholders in septage management 
The central government consists of several ministries. The number of ministries in the government, their responsibilities and thus also the institutions they are govern can change from government cabinet to government cabinet. The functions, duties and responsibilities of each ministry are decided by the president of the country in consultation with the prime minister. For example, according to Sri Lanka (2010), gazette notification 1681/3 (November 22, 2010), responsibilities for renewable energy development were assigned to the Ministry of Power and Energy. Subsequently, according to Sri Lanka (2013), gazette notification 1796/10 (February 6, 2013), the Ministry of Environment was upgraded to the Ministry of Environment and Renewable Energy, and the responsibilities for renewable energy development were transferred to this newly upgraded ministry. The discussion on the central government is centered on the core ministry that holds the responsibilities instead of an actual current profile of the ministry (that may have added responsibilities, which are, however, subject to change).

The regional level governance structure is referred to as 'Provincial Councils' and was established under Sri Lanka (1987), which is commonly known as the ' $13^{\text {th }}$ Amendment'. (i.e., the Provincial Council (PC) is a new addition to the Sri Lankan governing structure that came into effect as a result of the 13th amendment made to the 1978 Constitution in 1987). This administrative structure for decentralization of the powers vested in the central government, through nine regional-level intermediary provincial councils, created a linkage between the national level and the local level. It seems that many of the areas under the authority of the provincial councils are still not in a fully functional state (i.e., no institutional arrangements are in place to carry out the functions that fall under their responsibility). The environmental aspect, which includes septage disposal, is one of these areas that is not functional by the PCs yet.

The definition of 'waste' in legal terms had not been defined until 1980. This adopted definition can be identified as a significant step forward. Sri Lanka (1980), National Environmental Act No. 47 of 1980: section 33, defines the term 'waste' in a wider sense as follows: "waste includes any matter prescribed to be waste and any matter, whether liquid, solid, gaseous or radioactive, which is discharged, emitted, or deposited in the environment in such volume, constituency or manner as to cause an alteration of the environment." Clearly this also includes septage. Hence, it seems that any legal provisions applied for waste (unless categorized as solid waste, municipal solid waste, etc.) also applies for septage as well. 


\section{Local Level}

\section{Regulatory}

In Sri Lanka, many decades ago, human excreta was manually handled entirely. During this era, bucket latrines were common and excreta collected from bucket latrines were managed manually by LA staff. Night soil management has been mentioned as being a responsibility of the LAs in the acts and ordinances given below:

1) Municipal Council Ordinance No. 16 of 1947 - Sections 129, 130 and 131

2) Urban Council Ordinance No. 61 of 1939 - Sections 118, 119 and 120

3) Pradeshiya Sabha Act No. 15 of 1987 - Sections 93, 94 and 95

The contents of all three LA legislations regarding waste management are almost identical (though the Pradeshiya Sabha Act is comparatively recent) and, as an example, the content of the Municipal Council Ordinance No. 16 of 1947 is stated in Box 1.

\section{Box 1}

129. (b) For securing the due removal at proper periods of all house refuse, and the due cleansing any emptying at proper periods of all latrines and cesspits: and (c) for the proper disposal of all street refuse, house refuse and night-soil.

130. All street refuse, house refuse, night-soil, or other similar matter, collected in any Municipality under the provisions of this Part shall be the property of the Council, and the Council shall have full power to sell or dispose of all such matter and the money arising therefrom shall be paid to the credit of the Municipal Fund.

131. The Council shall, from time to time, provide places convenient for the proper disposal of all street refuse, house refuse, night-soil, and similar matter removed in accordance with the provisions of this Part, and for keeping all vehicles, animals, implements, and other things required for that purpose or for any of the other purposes of this Ordinance, and shall take all such measures and precautions as may be necessary to ensure that no such refuse, night-soil, or similar matter removed in accordance with the provisions of this Part is disposed of in such a way as to cause a nuisance 


\section{Institutional}

In all the above sections, night-soil management (though the terminology is not limited to bucket latrines) was focused on human excreta from bucket latrines, which was the on-site system at that time. Bucket latrines have disappeared almost completely from society with the introduction of the council collection service, while septic tanks and pit latrines have substituted these in most cases. Two major reasons for this transition were because LAs face difficulties in finding (a) a suitable labor force, and (b) dumping grounds for the nightsoil (Rajeswaran, 2013). Present on-site facilities act as storages. However, when these on-site storages are filled up they need to be emptied (collected, transported and disposed) and, as such, the responsibility of managing excreta is very much applicable here.

After bucket latrines disappeared, and until recently, septage from on-site sanitation systems were managed privately within the same plots of land without any involvement from LAs (though it is the responsibility of LAs). Due to the lack of labor, LAs did not get involved in on-site sanitation cleaning activities (pits) until the septic truck service was introduced (interview with Mrs. L. Mangalika, Additional Secretary, Ministry of Water Supply and Drainage). With increased urbanization, population growth and improved living standards, managing septage within the same premises is not considered as a favorable option anymore in the urban settings. More than a decade or so ago, a new urban service called 'septic truck service' (also called gully bowser service) was introduced to fill this new service gap. As in the past, septage from urban on-site sanitation systems now had to be collected, transported and disposed. Once again, being the responsible authority for this, LAs had to provide the requisite septage collection service. Until recently, these septic desludging services were solely under the control of LAs. However, the growing demand for septage management has begun to attract the private sector into this industry in a big way.

In general practice, urban waste (including septage) management is overseen by a standing committee on 'Environment and Health'. The Council can create bylaws (with approval from the regional and national authorities), which are only applicable to the respective LA boundaries (e.g., bylaws in Nuwara Eliya on septage management).

\section{Provincial Level}

\section{Regulatory}

The Provincial Council's direct responsibilities related to septage management cannot be found, but it has indirect supervisory powers. However, under List 1 subject 4, a Provincial Council has powers which include (a) supervision of 
the administration of local authorities established by law, and (b) conferring additional powers on local authorities. Under subject 37, protection of the environment within the province (to the extent permitted by law made by parliament) appears as part of the duties of the Provincial Council (GoSL, 2013).

\section{Institutional}

At present, the provincial government does not seem to be significantly involved in waste management. An excellent example to identify the kind of role that the Provincial Council can play is to consider the role of the Waste Management Authority of the Western Provincial Council (only provinciallevel authority) in solid waste management (for more details, please refer WPC, 2013). At present, provincial-level involvement in septage management is low and almost in a negligible state.

\section{National Level}

At the national level, it is hard to find a responsible authority or a focused law on septage management. However, there are legal provisions which are likely to be applied with regards to septage management. In the absence of a responsible authority, the main authorities and their provisions are stated below instead of analyzing the regulatory and institutional aspects separately.

\section{Government of Sri Lanka (GoSL)}

The vision of the Government of Sri Lanka (GoSL) is to aim at conserving the environment, by applying the principle that the 'abuser should pay for the abuse' (polluter pays). As a solution to the urban waste problem, GoSL is planning to claim all the waste generated in the Local Authority areas and convert it into biogas and organic fertilizer while recovering the resources (Ministry of Finance and Planning, 2010). This indicates that GoSL has a high interest in resource recovery and reuse as a solution to the final disposal of urban waste.

The vision of GoSL justifies that the areas with a comparatively dense population should be provided off-site sewerage facilities. The draft national sanitation policy mirrored this vision stating that, "off-site sanitation will be considered where on-site sanitation is not feasible - on-site sanitation is not feasible where housing and building densities are high as in many urban locations and the distance from point sources of water such as wells do not conform to stipulated standards, given the obtaining soil conditions. Onsite sanitation is also difficult where the water table is high and/or the soil conditions do not allow effective soakage and dispersion of wastewater." The policy further states that, in such cases, government subsidies will become 
unavoidable due to higher costs (Ministry of Water Supply and Drainage, 2012). Most of Sri Lanka is not highly urbanized and most of the urban areas are supplied with piped potable water. This gives a strong indication that the on-site sanitation coverage will become a predominant feature in Sri Lanka at least in the medium term, in parallel with other low-income countries. Hence, it is about time that septage management is considered more critically.

At the national level, as discussed, septage management responsibilities have not been very well defined yet. However, a host of authorities and legislations have an important role to play or have provisions in septage management. The major relevant authorities and their responsibilities have been discussed below in detail.

\section{Ministry of Water Supply and Drainage}

According to gazette notification number 1681/3 of November 22, 2010, the Ministry of Water Supply and Drainage has been vested with several powers, including water supply and sanitation projects. The National Water Supply and Drainage Board (NWSDB) has been assigned as an institute of the ministry.

\section{National Water Supply and Drainage Board (NWSDB)}

According to the powers entrusted to the NWSDB under Act No. 2 of 1974 - Section 17, the Board may exercise their powers over the management of sewerage (as mentioned earlier, septage only appeared as an urban waste a few years ago and, as such, only sewerage is mentioned in the Act): to establish, develop, operate and control an efficient, coordinated sewerage system; to takeover and carry out any water supply or sewerage undertaking; and to takeover and carry out any water supply or sewerage undertaking of any local authority. The NWSDB has a separate sewerage section which comes under an additional general manager of the Board. It is certain that the nationallevel technical and implementation capacities of septage treatment are with the NWSDB. However, the definition of 'sewerage systems' is not mentioned in the act, but appears as 'off-site systems'.

\section{Ministry of Local Government and Provincial Councils}

According to gazette notification number $1681 / 3$ of November 22, 2010, the Ministry of Local Government and Provincial Councils is responsible for implementing the Municipal Council Ordinance, Urban Council Ordinance, Pradeshiya Sabhas Act and the Provincial Council Act. As discussed earlier, local-level septage management responsibilities are with the LAs, but it is the ministry that is responsible for implementing the LA acts. The Provincial Councils do not seem to be playing an active role in septage management at present, and it is the ministry that has been entrusted with the responsibility of 
implementing the Provincial Council Act at the national level. Additionally, the Ministry of Local Government and Provincial Councils has been instructed to undertake the responsibility of formulating and implementing national policies in relation to subjects of Provincial Councils and Local Government.

\section{Ministry of Environment}

According to gazette notification number 1681/3 of November 22, 2010, the duties and functions of the Ministry of Environment include: (a) preservation of the environment for the present and future generations; and (b) formulation and effective implementation of programs to combat pollution of the environment. The ministry is also responsible for implementing Environmental Protection Acts, including the Marine Pollution Prevention Act (No. 35 of 2008) and National Environmental Act (No. 47 of 1980).

\section{Central Environmental Authority (CEA)}

The major role of the Central Environmental Authority (CEA) is to act as the national regulatory body on the subject of the environment. Powers vested to the authority under Act No. 47 of 1980 are: (a) to recommend to the minister, a national environmental policy and criteria for the protection of any portion of the environment with respect to the uses and values, whether tangible or intangible, to be protected, the quality to be maintained, the extent to which the discharge of wastes may be permitted without detriment to the quality of the environment and long range development used and planning and any other factors relating to the protection and management of the environment; and (b) to specify standards, norms and criteria for the protection of beneficial uses and for maintaining the quality of the environment.

According to Sri Lanka (2008) - gazette notification no. 1534/18 of February 1, 2008, among the amendments introduced to the National Environment Act, No. 47 of 1980, the Environmental Protection License (EPL) for Emission or Disposal of Waste was also included. According to the law, no person shall, discharge, deposit or emit waste into the environment or carry on any prescribed activity determined by an Order made under Section 23A of the National Environmental Act, No. 47 of 1980 in circumstances which cause or are likely to cause pollution, or noise pollution, otherwise than the license issued by the CEA and in accordance with the standards and criteria specified.

The National Environmental (Protection and Quality) Regulations, No. 1 of 1990, has established discharge standards and made it an offence to discharge, deposit or emit waste into the environment that will cause pollution, except in the following circumstances: a) under the authority of a license from the CEA; and b) subject to prescribed standards and criteria. 
National Environmental (Protection and Quality) Regulation (EPL) of 1990. As per gazette notification number 595/16 of January 8,1990 , and its amendment with gazette notification number 1534/18 of February 1, 2008 specifies additionally "the 'general standards' for discharge of effluents into inland surface waters."

As discussed above, the regulatory discharge standards seem to have already been established. Nevertheless, application of the provisions in relation to septage disposal is still to be implemented.

Ministry of Environment, 2003 (National Environmental Policy, Section 2.2.8) states, "The impact on, and risks to, environmental quality and public health will be reduced to levels that are socially acceptable by managing waste streams. This will be supported by the prevention of the harmful effects of hazardous substances and through the clean up of existing contaminated sites."

\section{Ministry of Agriculture and Ministry of Health}

The vision of the Government of Sri Lanka (GoSL) is to recommend the recovery of resources from urban waste. In order to achieve this, the Ministry of Agriculture would probably have a major role to play when nutrient is recovered from septage as an organic fertilizer. As of gazette notification number $1681 / 3$ of November 22,2010, the ministry's duties include agricultural diversification, agriculture production improvement, development of hightech agriculture, etc. The same gazette mentions the duties and obligations of the Ministry of Health which include the formulation of policies, programmes and projects in regard to the subjects of health, nutrition, disease prevention, etc., which also play a vital role in the safe resource recovery process.

\section{Urban Development Authority (UDA)}

The amendment to Sri Lanka, 1982 (UDA Act) lays down components to the development plan, including control of pollution and environmental qualities. Lands for waste management activities have also been earmarked. It should be noted that the UDA only works on declared urban development areas which have been mentioned in gazette notifications.

\section{Sri Lanka Police}

Sri Lanka, 1865 (The Police Ordinance) Section 63(g) has provisions in relation to improper disposal of waste. It states "any person who throws or lays down any dirt, filth, rubbish, or any stones or building materials can be taken into custody without a warrant if the person in view of the officers has committed any such offence. Such offences are liable to a fine or imprisonment not exceeding three months." 
There are a few more Acts which have minor provisions on septage, such as the Sri Lanka, 1981 (Coast Conservation Act); Sri Lanka, 1964 (Water Resources Board Act); Sri Lanka, 2008 (Marine Pollution Prevention Act, which states, for example, "to take measure to manage, safeguard and preserve the territorial waters of Sri Lanka or any other maritime zones, it's fore shore and coastal zone of Sri Lanka from any pollution caused by any oil, harmful substance or any other pollutant" Section $6(\mathrm{~d})$ ), etc. In addition to these, there are a few Sri Lankan Standards (SLS) which are complementary and not legally binding standards such as SLSI (1984), where tolerance limits for industrial effluent discharge into inland surface waters are mentioned, e.g., SLSI (2004) on septic tank design and associate soakaway system, etc.

\section{Discussion}

In Sri Lanka, a host of National Acts provide regulations on wastewater management and solid waste management, but none of them specifically address septage management. Presently, there is no direct policy or guidelines for the safe handling, transport and disposal of septage in the country (see Figure 2). Some of the authorities have broad legal powers via regulatory provisions, but do not have the capacity or the mandate to work on septage.

It is clear that septage management responsibilities at the local level are well defined to the LAs. The LAs are obliged to adhere to all the activities along the entire sanitation value chain (from the collection of night-soil (excreta) to final disposal). However, guidelines or manuals on collection, transport and disposal are not available to the LAs, but information on tank construction according to SLS complementary standard is available. It is observed that there is an emergence of private sector participation in septage collection, but with no proper guidelines or legal provisions in place this might make the situation more uncontrollable as shown in Table 1. Availability of the regulatory provisions has been visualized in Figure 2.

As shown in Table 1, it is understood that there is a need for septage management policies, regulations and guidelines in Sri Lanka covering national to local level. However, there are some urban waste management and environmental provisions that may be applicable in a broader sense or via few decentralized documents as discussed.

At the provincial level, activities related to waste management are limited. For example, out of the nine provincial councils, only in the Western Province is there some kind of arrangement to work on waste management (but, that too is limited to solid waste). However, Provincial Councils have direct control over LAs, including their waste management activities. By considering the capacities and the almost negligible involvement of PCs on septage management at present, it is difficult to expect regulatory initiatives at the 
provincial level until their capacities are built to a higher level. It should be noted that the central government has powers to determine national policies even on subjects devolved to the PC (Central Environmental Authority, 2009). This seems to be the most practical way forward.

Table 1. Regulation and availability

\begin{tabular}{|c|c|}
\hline Responsibility/Regulation & Availability \\
\hline \multicolumn{2}{|c|}{ National level } \\
\hline National responsible agency & No \\
\hline National policy & No \\
\hline National guidelines & No \\
\hline On-site sanitation standards & Yes $^{3}$ (SLS for toilet construction) \\
\hline Septage compost standards & No \\
\hline Sanitation policy & $\begin{array}{l}\text { Yes (Ministry of Water Supply } \\
\text { and Drainage-draft policy) }\end{array}$ \\
\hline Discharge limits & $\begin{array}{l}\text { Yes (Central Environmental Au- } \\
\text { thority) }\end{array}$ \\
\hline Manuals & No \\
\hline \multicolumn{2}{|c|}{ Provincial level } \\
\hline Provincial responsibility & Yes $^{1}$ (Provincial Council) \\
\hline Provincial regulations & No \\
\hline \multicolumn{2}{|c|}{ Local level } \\
\hline Local-level responsibilities & Yes (Local Authority) \\
\hline Bylaws & $\mathrm{No}^{2}$ \\
\hline
\end{tabular}

1 Though the PC has responsibilities, it does not play an active role

2 No specific bylaws are available, in general (except for the Nuwara Eliya Council)

3 Covering septic tanks

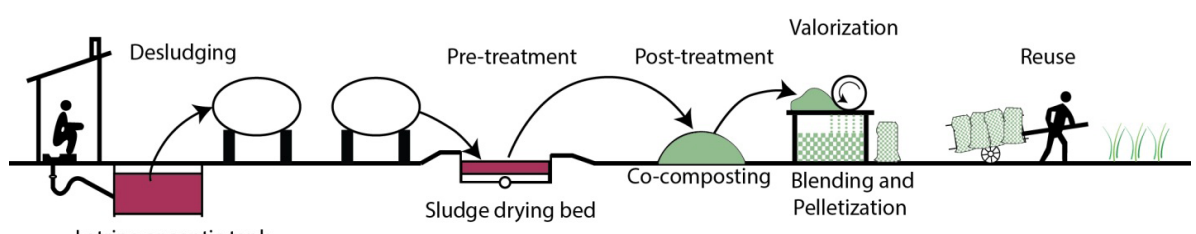

Latrine or septic tank

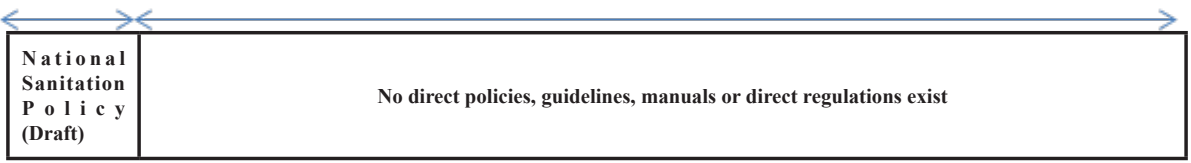

Figure 2 - Sanitation value chain (source: IWMI unpublished) 
At present, septage management in Sri Lanka operates largely in a grey area as a result of the unavailability of dedicated legal provisions. Practically, this regulatory gap should be filled at the national level first. The various responsibilities with regards to different aspects of regulations have been delegated to different authorities. The complexity of the institutional responsibility in decentralization is shown in Figure 3.

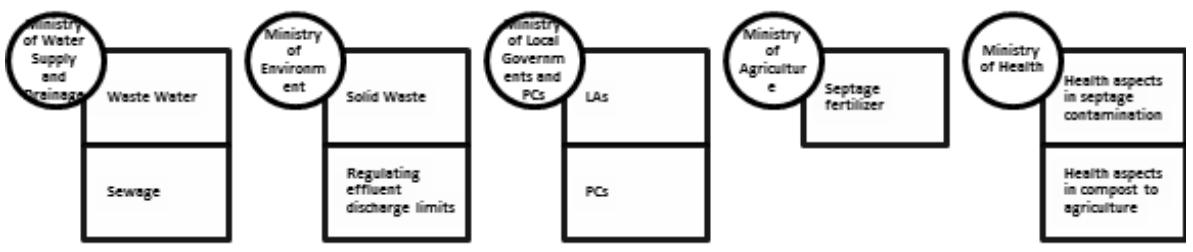

Figure 3 - Major ministries with responsibilities

The responsibility of septage management (including reuse) has been divided among a number of central government ministries. Having an apex body consisting of the above ministries under the leadership of the Ministry of Water Supply and Drainage seems to be a possible way forward. The National Solid Waste Management Support Centre (to manage solid waste), an apex body co-chaired by the secretaries of the ministries of Environment, Local Government and Provincial Councils could be seen as a potential model.

\section{Conclusions}

* At present, septage is one of the most neglected urban waste streams in Sri Lanka. By considering an increase in access to septic truck services and growing private sector participation, septage management needs attention. If left unmanaged, septage can create an adverse impact on the environment and the health of the people.

* Responsibility of septage management at the local level is clearly assigned to the LAs. At the provincial level, the responsibilities are with the PCs, but they do not play an active role in managing septage. The national responsibility with regards to septage management is scattered among many different ministries. As the capacities are limited at the provincial level, the practical way forward would be to allow nationallevel regulations to spill over to the local level.

As discussed, the responsibility of septage management has dropped to a great extent in all three tiers of the governance level.

Environmental pollution and associated health risks associated with present dumping practices, call for an integrated approach to prevent pollution and highlights the vital need for effective interventions. As 
the Ministry of Water Supply and Drainage has the capacity to provide leadership to this initiative, the apex body consisting of relevant ministries under its auspices seems to be a possible way forward.

* In order to achieve sustainable septage management on the ground, capacity building at provincial and local level should be considered, including the private sector.

* While filling all the institutional gaps for the proper functioning of this sector, regulatory provisions for septage management should also be introduced from the national level to the local level across the scale.

\section{References}

AECOM International Development, Inc.; Department of Water and Sanitation in Developing Countries, Swiss Federal Institute of Aquatic Science and Technology - Sandec/Eawag (2010) A rapid assessment of septage management in Asia: Policies and practices in India, Indonesia, Malaysia, the Philippines, Sri Lanka, Thailand, and Vietnam. Thailand: United States Agency for International Development (USAID), Regional Development Mission for Asia (RDMA). Available at http://pdf.usaid.gov/pdf_docs/PNADS118.pdf(accessed on September 18, 2013).

Central Environmental Authority (2009) Report on strengthening the existing regulatory mechanism and legal framework for solid waste. Kaduwela: Nipuna Print.

Ceylon. The Police Ordinance (1865) (No. 16) Colombo. Legislative council of Sri Lanka.

Ceylon. Urban Council Ordinance 1939 (No. 61). Legislative council of Sri Lanka.

Democratic Socialist Republic of Sri Lanka. Coastal Conservation Act (1981) (No. 57). Sri Jayawardenapura : Parliament of Sri Lanka.

Democratic Socialist Republic of Sri Lanka. Marine Pollution Prevention Act (2008) (No. 2) Sri Jayawardenapura : Parliament of Sri Lanka.

Democratic Socialist Republic of Sri Lanka. Municipal Council Ordinance (1947) (No. 16). Sri Jayawardenapura : Parliament of Sri Lanka.

Democratic Socialist Republic of Sri Lanka. National Environmental Act (1980) (No. 47). Sri Jayawardenapura : Parliament of Sri Lanka.

Democratic Socialist Republic of Sri Lanka. National Water Supply Drainage Board Law (NWSDB) (1974) (No. 2). Colombo: Parliament of Sri Lanka. 
Democratic Socialist Republic of Sri Lanka. Pradeshiya Sabha Act (1987) (No. 15). Sri Jayawardenapura : Parliament of Sri Lanka.

Democratic Socialist Republic of Sri Lanka. Provincial Council Act (1987) (No. 42). Sri Jayawardenapura : Parliament of Sri Lanka.

Democratic Socialist Republic of Sri Lanka. The Gazette of the Democratic Socialist Republic of Sri Lanka (1990) Government notifications. No. 595/16, 01 February. Department of Government Printing.

Democratic Socialist Republic of Sri Lanka, The Gazette of the Democratic Socialist Republic of Sri Lanka (2008) Government notifications. No. 1534/18, 01 February. Department of Government Printing.

Democratic Socialist Republic of Sri Lanka, The Gazette of the Democratic Socialist Republic of Sri Lanka (2010) Government notifications. No. 1681/3, 22 November. Department of Government Printing .

Democratic Socialist Republic of Sri Lanka, The Gazette of the Democratic Socialist Republic of Sri Lanka (2013) Government notifications. No. 1796/10, 06 February. Department of Government Printing.

Democratic Socialist Republic of Sri Lanka. Urban Development Authority Act. 1982 (No. 4) Colombo: Parliament of Sri Lanka.

Democratic Socialist Republic of Sri Lanka. Water Resource Board Act 1964 (No. 29). Colombo: Parliament of Sri Lanka.

GOSL - Government of Sri Lanka (2013) Provincial Councils [on line]. [Accessed on 22.10.2013]. Available at http://www.priu.gov.lk/ ProvCouncils/ProvicialCouncils.html\#A6

Hingorani, P. (2014). The economics of municipal sewage water recycling and reuse in India Chapter 21 [on line]. [Accessed on 22.10.2013]. Available at http:/www.idfc.com/pdf/report/2011/Chp-21-The-Economics-ofMunicipal-Sewage-Water-Recycling.pdf

Mangalika, L. - interviewee (2013) Interview with L. Jayawardane. 22 October 2013, Colombo.

Ministry of Environment (2003) National environmental policy. Colombo: Ministry of Environment.

Ministry of Finance and Planning (2010) Sri Lanka the emerging wonder of Asia: Mahinda chintana vision for the future: The development policy framework. Sri Lanka: Government of Sri Lanka Pp. 62, 158.

Ministry of Water Supply and Drainage (2012) National sanitation policy, Unpublished, Colombo: Ministry of Water Supply and Drainage Pp.1. 
Narain, S (2012) Excreta matters - how urban India is soaking up water, polluting rivers and drowning in its own waste. Vol. 1, Pandey P. (ed.) New Delhi: Centre for Science and Environment.

IWMI - International Water Management Institute (2013). Guideline for process selection and design - Recovery of nutrients and organic matter from faecal sludge. Colombo, Sri Lanka: (forthcoming).

NSWMSC - National Solid Waste Management Support Centre (2012) Data base on faecal sludge management in Sri Lanka: National Solid Waste Management Support Centre, Unpublished, Ministry of Local Government and Provincial Councils.

Rajeswaran S.T.B. (2013) UNDP/UN-HABITAT sponsored sustainable cities programme: Jaffna urban governance support project city profile [on line]. [Accessed on 22.10.2013]. Available at http://www.unhabitat.1k/ downloads/SCP/Jaffna.pdf

Sandec/Eawag (Department of Water and Sanitation in Developing Countries, Swiss Federal Institute of Aquatic Science and Technology); IWA (International Water Association); ONAS (National de l'Assainissement du Sénégal) (2006) Urban excreta management - Situation, challenges, and promising solutions. Report on first international faecal sludge management policy symposium and workshop, Dakar, Senegal, May 9-12, 2006. Pp. ii.

SLSI - Sri Lanka Standard Institution (1984) Tolerance limits for industrial effluents discharge into inland surface water - SLS 652:1984. Colombo: SLSI.

SLSI - Sri Lanka Standard Institution (2004) Septic tank design and associate soakaway system SLS 745:2004. Colombo: SLSI.

WPC - Western Provincial Council (2013) Waste Management Authority [on line]. [Accessed on 10.04.2013]. Available at http://www.wpc.gov.lk/ chief-ministry-waste-01.htm\#Aims $\% 20$ and $\% 20$ Objectives $\%$ A0 